\section{Punc BIBLIO COUNS}

Biblio Couns : Jurnal Kajian Konseling dan Pendidikan

Vol. 1, No. 2, Juli 2018, hlm. 35 - 42

Tersedia Online di jurnal.umsu.ac.id/index.php/biblio

ISSN 2620-3103 (online)

DOI : https//doi.org/10.30596/bibliocouns.v1i2.2076

\title{
Efikasi Diri terhadap Kinerja Karyawan PDAM Tirtanadi Unit Instalasi Pengolahan Air Sunggal
}

\author{
Sri Ngayomi Yudha Wastuti, S.Psi.,M.Psi.,Psi. \\ Program Studi Bimbingan dan Konseling Universitas Muhammdiyah Sumatera Utara \\ sringayomi@umsu.ac.id
}

\begin{abstract}
His study aims to determine the effect of the self efficacy with employee performance at PDAM Tirtanadi.This study uses quantitative method with the number of samples as many as 40 people with try out system used, meaning that data have been taken in the test scale, re used as data for hypothesis testing. This research uses simple regression analysis method. Based on the data analysis obtained the results 1) There is a significant influence between self-efficacy on employee performance. It is shown by coefficient Freg = 97,611 where $p<0,050$. Indicates that the higher the self efficacy will be the better employee performance, and the lower the self-efficacy will be the worse employee performance. 2) There is a positive influence between self-efficacy on employee performance at PDAM Tirtanadi Sunggal Branch employee with $72 \%$ contribution. From these results it is known that there is still $28 \%$ influence from other factors on employee performance. 3) Another result is obtained from this research, which is known that the subject of this research the employees of Tirtanadi PDAM Sunggal Branch, has a very high self-efficacy with employee performance obtained is also quite high. This is known by looking at the empirical mean / self efficacy mean value (175.08) and the hypothetical average value (105). Furthermore, for employee performance it is known that the mean mean / empirical mean $(85,88)$ and the hypothetical mean is $(8)$.
\end{abstract}

Keywods : Self Efficacy, Employee performance

\section{Abstrak}

Penelitian ini bertujuan untuk melihat pengaruh antara efikasi diri dengan kinerja karyawan pada PDAM Tirtanadi khususnya di Unit Instalasi Pengolahan Air Sunggal.

Penelitian ini menggunakan metode kuantitatif dengan jumlah sampel sebanyak 40 orang dengan sistem try out terpakai, artinya data yang sudah diambil dalam uji coba skala ukur, kembali digunakan sebagai data untuk pengujian hipotesis. Penelitian ini menggunakan metode analisis regresi sederhana. Berdasarkan analisis data diperoleh hasil 1) Terdapat pengaruh yang signifikan antara efikasi diri terhadap kinerja karyawan. Hal ini ditunjukan dengan koefisien $F_{\text {reg }}=97,611$ dimana $p<0,050$. menandakan bahwa semakin tinggi efikasi diri maka akan semakin baik kinerja karyawan, dan sebaliknya semakin rendah efikasi diri maka akan semakin buruk kinerja karyawan. 2) Ada pengaruh yang positif antara efikasi diri terhadap kinerja karyawan pada pegawai PDAM Tirtanadi Cabang Sunggal dengan sumbangan $72 \%$. Dari hasil ini diketahui bahwa masih terdapat $28 \%$ pengaruh dari faktor lain terhadap kinerja karyawan. 3) Hasil lain diperoleh dari penelitian ini, yakni diketahui bahwa subjek penelitian ini para pegawai PDAM Tirtanadi Cabang Sunggal, memiliki efikasi diri yang tergolong sangat tinggi dengan kinerja karyawan yang diperoleh juga tergolong sangat tinggi. Hal ini diketahui dengan melihat nilai rata-rata/mean empirik efikasi diri $(175,08)$ dan nilai rata-rata hipotetiknya (105). Selanjutnya untuk kinerja karyawan diketahui bahwa mean rata-rata/mean empiriknya (85,88) dan mean hipotetiknya adalah (8).

Kata kunci : Efikasi Diri, Kinerja Karyawan. 


\section{PENDAHULUAN}

Perusahaan sebagai sebuah organisasi merupakan kesatuan sosial yang dikoordinasikan secara sadar, dengan sebuah batasan yang relatif dapat diidentifikasi, bekerja secara terus menerus untuk mencapai tujuan tertentu. Definisi tersebut secara eksplisit mengasumsikan kebutuhan untuk mengkoordinasikan pola interaksi manusianya. Pola interaksi sumber daya manusia dalam organisasi harus diseimbangkan dan diselaraskan agar organisasi dapat tetap eksis.

Faktor manusia memegang peranan penting dalam upaya pembangunan sektor industri karena manusia merupakan kekuatan sentral yang menggerakkan dinamika organisasi. Peranan sumber daya manusia dalam suatu organisasi dewasa ini telah disadari oleh perusahaan. Maju mundurnya suatu perusahaan sangat tergantung pada faktor manusia yang terdapat didalamnya. Berbagai persoalan pada organisasi setelah ditelusuri penyebabnya akan kembali pada individu (karyawan) yang terlibat di dalamnya. Meskipun sumber daya modal, bahan mentah, dan teknologi yang dimiliki perusahaan sangat baik, namun tanpa didukung oleh sumber daya manusia yang kompeten, maka kegiatan produksi di perusahaan tidak akan dapat berjalan dengan lancar.

Setiap waktu organisasi selalu dihadapkan dengan tuntutan untuk melaksanakan perubahan agar usahanya dapat bertahan sesuai dengan tuntutan dari perubahan itu sendiri. Pelaksanaan perubahan tentunya diharapkan menuju kearah yang lebih baik. Robbins (2006) mengatakan bahwa tujuan perubahan ada dua yaitu untuk meningkatkan kemampuan perusahaan dalam beradaptasi dengan perubahan yang terjadi didalam lingkungannya, dan untuk merubah tingkah laku dari para karyawannya dalam organisasi. Dengan demikian karyawan organisasi, memegang peranan penting dalam proses perubahan karena organisasi tidak dapat berjalan sendiri tanpa sumber daya manusia yang baik.

Karyawan merupakan unsur terpenting dalam menentukan maju mundurnya suatu perusahaan. Untuk mencapai tujuan perusahaan diperlukan karyawan yang sesuai dengan persyaratan dalam perusahaan, dan juga harus mampu menjalankan tugas-tugas yang telah ditentukan oleh perusahaan. Setiap perusahaan akan selalu berusaha untuk meningkatkan kinerja karyawannya, dengan harapan apa yang menjadi tujuan perusahaan akan tercapai. Ada beberapa faktor yang dapat meningkatkan kinerja karyawan menurut Simamora (2004) adalah faktor individual seperti kemampuan dan keahlian, faktor psikologis seperti presepsi, sifat, sikap, serta motivasi, dan faktor organisasi seperti kepemimpinan dan job design.

Di era globalisasi ini, perusahaan dituntut untuk memiliki SDM yang unggul agar dapat terus mempertahankan eksistensinya. Perusahaan akan bersaing tidak hanya dengan perusahaan lokal saja namun perusahaan akan bersaing dengan perusahaan dari mancanegara.Persaingan bisnis ini juga berpengaruh terhadap PDAM Tirtanadi yang merupakan operator sistem pengelolaan air limbah Kota Medan, dimana tujuan pokok dari PDAM Tirtanadi adalah untuk mengelola dan menyelenggarakan pelayanan air minum yang memenuhi persyaratan kesehatan dan untuk mengembangkan perekonomian daerah, meningkatkan pendapatan daerah, serta meningkatkan kualitas lingkungan dengan memberikan pelayanan pengumpulan dan penyaluran air limbah melalui sistem perpipaan dalam rangka untuk mencapai kesejahteraan masyarakat pada umumnya (Website PDAM Tirtanadi, 2015). Untuk itu dibutuhkan SDM yang handal untuk dapat memberikan kontribusinya bagi perusahaan, oleh karena itu PDAM Tirtanadi harus terus meningkatkan kualitas sumber daya manusianya kaitannya dengan kinerja karyawan.

Timbulnya permasalahan kinerja bersumber dari variabel-variabel yang mempengaruhi kinerja tersebut. Secara teoretis menurut Kreitner dan Kinicki (2013) variabel-variabel tersebut adalah individual inputs, motivasi dan kombinasi faktor-faktor yang memungkinkan dan membatasi job context. Individual inputs yaitu: kemampuan, pengetahuan, kepribadian, sifat-sifat, emosi, suasana hati, keyakinan dan nilai-nilai bekerja. Job context yaitu lingkungan fisik, rancangan tugas, imbalan, penguatan, dukungan supervisor dan penyelia, norma-norma sosial dan budaya organisasi. Selain variabel ini menurut Robbins dan Judge (2014) masih terdapat variabel efikasi diri, yaitu keyakinan individu bahwa dirinya mampu mengerjakan suatu tugas. 
Secara empirik berapa hasil penelitian telah menguji variabel-variabel yang mempengaruhi kinerja seperti, hasil penelitian Samsudin (2005) menunjukkan bahwa kinerja dipengaruhi oleh tingkat pendidikan, pelatihan yang diikuti, motivasi, pengalaman kerja, sikap loyal dan budaya kerja. Hal ini didukung oleh hasil penelitian Arianti (2005), Megawati (2004), Mardalena (2004). Selain variabelvariabel tersebut menurut Rijal (2006) variabel imbalan, umur, fisik dan kepribadian dapat mempengaruhi kinerja individu pada organisasi.

Organisasi dapat mencapai kinerja yang diharapkan serta memiliki keunggulan kompetitif adalah ketika orang didalamnya melakukan apa yang terbaik dari mereka. Selain itu adanya perubahan yang terjadi seperti tekanan dalam pelayanan publik, tekanan informasi, tekanan lingkungan, harapan karyawan untuk berkembang, struktur dan ukuran organisasi dan lain-lain juga akan mendorong organisasi untuk selalu meningkatkan kinerja organisasi dan kinerja karyawan agar dapat bersaing secara global.

Kinerja karyawan yang tinggi menurut Steers (dalam Suharto dan Cahyono, 2005) di dukung dengan kualitas personal yang tinggi, dimana kualitas personal akan memunculkan keyakinan terhadap kemampuan yang dimiliki keadaan ini akan mengarahkan individu merasa gairah dalam bekerja sehingga individu merasa puas terhadap hasil kerjanya.

Kualitas pribadi yang dimaksud, salah satunya adalah dimilikinya individu dalam hal ini karyawan dengan efikasi diri yang tinggi. Karyawan yang memiliki efikasi diri tinggi akan cenderung mampu dan yakin menghadapi kesulitan-kesulitan yang dihadapi dalam organisasi, karena bagi mereka hal itu merupakan tantangan, sehingga ketika menghadapi kondisi kerja yang berpotensi menimbulkan ketidakpuasan kerja, hal itu tidak berdampak pada menurunnya kepuasan kerja mereka, namun justru mendorong mereka untuk tetap berada di dalamnya dan menghadapi berbagai kesulitan yang ada. Dalam kehidupan sehari-hari, efikasi diri memimpin kita untuk menentukan cita-cita yang menantang dan tetap bertahan dalam menghadapi kesulitan-kesulitan. Lebih dari seratus penelitian memperlihatkan bahwa efikasi diri meramalkan produktivitas pekerja. Ketika masalah-masalah muncul, perasaan efikasi diri yang kuat mendorong para pekerja untuk tetap tenang dan mencari solusi daripada merenung ketidakmampuannya. Usaha dan kegigihan menghasilkan prestasi. Sehingga, dari sini menunjukkan bahwa efikasi diri berbanding lurus dengan kinerja dalam arti untuk meraih suatu prestasi.

Dengan demikian, dapat disimpulkan bahwa efikasi diri merupakan suatu keyakinan terhadap diri sendiri yang muncul dalam menyelesaikan/mengatasi beraneka ragam situasi yang muncul dalam hidupnya.Keyakinan kepada kemampuan sendiri mempengaruhi motivasi pribadi, makin tinggi efikasi diri maka tingkat stres makin rendah. Sebaliknya, makin tinggi keyakinan kepada kemampuan sendiri, maka makin kokoh tekadnya untuk menyelesaikan tugas dengan baik. Keyakinan kepada efikasi mempengaruhi tingkat tantangan dalam menyelesaikan tugas. Secara singkat dapat dikatakan bahwa bukan hanya kemampuan kerja yang menentukan keberhasilan pelaksanaan tugas, melainkan juga ditentukan oleh tingkat keyakinan pada kemampuan sehingga dapat menambah intensitas motivasi dan kegigihan kerja karyawan. Definisi tersebut dikaitkan dengan pengambilan keputusan atas kemampuan yang dimiliki seseorang dalam menghadapi situasi di masa mendatang.

Di dalam melaksanakan berbagai tugas, orang yang mempunyai efikasi diri tinggi adalah orang yang berkinerja sangat baik. Mereka yang mempunyai efikasi diri dengan senang hati menyongsong tantangan, sedangkan mereka yang memiliki efikasi diri rendah akan merasa keberatan untuk mencoba tantangan, tidak peduli betapa baiknya kemampuan mereka yang sesungguhnya. Rasa percaya diri meningkatkan hasrat untuk berprestasi, sedangkan keraguan menurunkannya. Tingkat efikasi diri merupakan alat prediksi yang lebih tepat untuk kinerja seseorang dibandingkan keterampilan atau pelatihan yang dimiliki sebelum seseorang dipekerjakan (Goleman,1999). Tingkat efikasi diri ditentukan oleh pengalaman sebelumnya (kesuksesan dan kegagalan), pengalaman yang diakui oleh orang lain (dengan mengamati kesuksesan dan kegagalan orang lain), persuasi verbal (dari teman, kolega, saudara) dan keadaan emosi (kekhawatiran). Persepsi yang dimiliki oleh seseorang terhadap kemampuannya untuk melaksanakan tugas akan meningkatkan kemungkinan tugas tersebut dapat diselesaikan dengan sukses.

Bandura (1994) menjelaskan bahwa efikasi diri yang kuat dapat meningkatkan prestasi dan kepribadian yang baik dalam berbagai hal. Individu yang memiliki efikasi diri tinggi, yang berarti ia 
yakin terhadap kemampuan diri untuk melaksanakan berbagai tugas dalam berbagai situasi, akan menganggap tugas-tugas yang sukar sebagai tantangan untuk diatasi daripada sebagai ancaman yang harus dihindari. Pandangan efikasi seperti itu akan membantu perkembangan minat instrinsik dan memikat pada kegiatan-kegiatan yang lebih mendalam. Mereka menetapkan tujuan-tujuan yang menantang dan memelihara komitmen yang kuat terhadap tujuan tersebut, serta memotivasi diri untuk mencapainya dengan meningkatkan dan mempertahankan usaha-usaha mereka menghadapi kegagalan. Mereka dengan cepat akan memulihkan rasa efikasinya setelah mengalami kegagalan atau kemunduran.

Brown \& Leigh (1996) mengatakan efikasi diri menunjukkan bahwa individu yang memiliki kepercayaan diri bahwa ia mampu melakukan pekerjaan dengan sukses akan merasa lebih bahagia dengan pekerjaannya, sehingga mereka akan lebih fokus dalam pekerjaannya dan akan mengarahkan kepada kinerja yang lebih baik. Dalam kata lain, dalam melakukan aktivitas pekerjaannya, individu lebih didorong oleh minat instrinsiknya. Keadaan ini selanjutnya dapat menumbuhkan rasa kepuasan kerja yang lebih besar. Hal ini diperkuat dengan hasil penelitian dari Rahmani Wulandari (2009) bahwa seseorang yang merasa dirinya begitu berharga dan berarti cenderung untuk melakukan yang terbaik dalam setiap tugas dan memiliki berbagai macam permasalahan dalam mengelola sumber daya manusianya. Disamping itu efikasi diri berpengaruh positif dan signifikan terhadap kinerja pegawai, apabila persepsi pegawai tentang faktor efikasi diri yang diukur dengan indikator efikasi diri yang disampaikan meliputi jenis kelamin, usia, tingkat pendidikan dan pengalaman sesuai dengan bidang semakin tinggi efikasi diri seseorang, semakin besar pula kepercayaan dari orang tersebut terhadap kesanggupannya untuk berhasil dalam mencapai tujuan, Fadiarni Widyaning Putri (2015).

Permasalahan mengenai kinerja karyawan pada PDAM Tirtanadi khususnya di Unit Instalasi Pengolahan Air Sunggal sebenarnya tidak ada, namun mengingat bahwa kinerja karyawan sangat penting dalam mencapai produktifitas, maka peneliti tertarik untuk melihat faktor apa sajakah yang berpengaruh dalam menciptakan kinerja karyawan yang tinggi.

Dari uraian di atas peneliti tertarik untuk melakukan penelitian dengan judul "Pengaruh Antara Efikasi Diri terhadap Kinerja Karyawan PDAM Tirtanadi di Unit Instalasi Pengolahan Air Sunggal".

\section{METODE}

Adapun variabel-variabel dalam penelitian ini adalah :

a. Variabel bebas, sebagai variabel yang mempengaruhi variabel lainnya yaitu Efikasi Diri (X1),

b. Variabel terikat, sebagai variabel yang dipengaruhi variabel lainnya yaitu Kinerja Karyawan (Y1).

Populasi dalam penelitian ini adalah karyawan/i PDAM Tirtanadi di Unit Instalasi Pengolahan Air Sunggal, Medan, yang berjumlah 40 orang karyawan.

Dalam penelitian ini, metode yang digunakan dalam mengumpulkan data adalah metode dokumentasi untuk data kinerja karyawan. Metode dokumentasi diambil dari dokumentasi perusahaan, digunakan untuk melihat dan mengumpulkan data tentang kinerja karyawan, yaitu berupa Blanko Penilaian Kinerja Karyawan. Sedangkan untuk efikasi menggunakan metode angket yang disusun berdasarkan aspek efikasi diri, dari teori Bandura (1997) yakni : a. Tingkat (level), b. Keluasan (generality), c. Kekuatan (strength), dalam bentuk skala Likert. Penilaian antara setuju dengan tidak setuju dapat dibagi menjadi empat kategori. Sedang bentuk pernyataannya dapat dikelompokkan menjadi 2 (dua), yaitu pernyataan yang favorable dan pernyataan yang unfavorable. Sistem penilaian keempat kategori tersebut, untuk pernyataan yang favourable, yaitu: sangat setuju (SS) nilai 4 setuju (S) nilai 3, tidak setuju (TS), sangat tidak setuju (STS) nilai 1. Kemudian untuk pernyataan unfavourable, yaitu: sangat setuju (SS) nilai 1, setuju (S) nilai 2, tidak setuju (TS) nilai 3, sangat tidak setuju (STS) nilai 4.

Selanjutnya berdasarkan hasil uji coba skala Efikasi diri yang berjumlah 50 butir, diketahui bahwa terdapat 8 aitem yang gugur, yakni aitem 31, 32, 39, 41, 42, 43, 46, dan 47. Sehingga aitem yang valid berjumlah 42 aitem dan keseluruhan aitem yang valid memiliki koefisien korelasi $\mathrm{r}_{\mathrm{bt}}=$ 
0,355 sampai $r_{b t}=0,708$. Tabel berikut merupakan distribusi penyebaran butir skala Efikasi

Diri setelah uji coba.

Teknik analisis data yang digunakan dalam penelitian ini adalah Analisis Regresi sederhana, dimana teknik ini akan dilihat bagaimana pengaruh Efikasi diri terhadap kinerja pegawai PDAM Tirtanadi di Unit Instalasi Pengolahan Air Sunggal. Namun, sebelum data dianalisis dengan teknik Analisis Regresi Sederhana, terlebih dahulu dilakukan uji asumsi dan uji hipotesis penelitian.

Hasil dari uji asumsi untuk normalitas sebaran diketahui bahwa variabel efikasi diri mengikuti sebaran normal, yaitu berdistribusi sesuai dengan prinsip kurve normal Ebbing Gauss. Sebagai kriterianya apabila $\mathrm{p}>0,050$ maka sebarannya dinyatakan normal, sebaliknya apabila $\mathrm{p}<$ 0,050 sebarannya dinyatakan tidak normal (Hadi dan Pamardingsih, 2000).

Sedangkan uji hipotesis di peroleh bahwa nilai koefisien kolerasi (rxy) sebesar 0,848, rtabel sebesar 0,418. Jadi rhitung > rtabel. Tampak adanya pengaruh efikasi diri terhadap kinerja karyawan PDAM Tirtanadi di unit pengolahan air Sunggal.

\section{HASIL PENELITIAN}

Hasil penelitian ini membuktikan bahwa terdapat pengaruh yang signifikan antara Efikasi diri terhadap kinerja pegawai. Hal ini ditunjukan dengan koefisien $F_{\text {reg }}=97,611$ dimana $p<0,050$. Ini menandakan bahwa semakin tinggi efikasi diri maka akan semakin baik kinerja karyawan, dan sebaliknya semakin rendah efikasi diri maka akan semakin buruk kinerja karyawan.

Hasil penelitian ini dikuatkan dengan pandangan Liden dkk. (2000) yang mengemukakan hasil riset pada efikasi diri menunjukkan bahwa individu yang memiliki kepercayaan diri bahwa ia mampu melakukan pekerjaan dengan sukses akan merasa lebih bahagia dengan pekerjaannya, dibandingkan dengan individu yang takut bahwa kemungkinan mereka gagal. Ketakutan akan kegagalan akan membuat individu mengalami perasaan ketidakberdayaan, dibandingkan dengan individu yang percaya diri bahwa dirinya kompeten. Individu dengan efikasi diri tinggi berarti lebih terlibat, lebih bertanggungjawab, lebih menikmati, dan lebih bahagia dengan pekerjaan yang menjadi tanggungjawabnya. Keadaan ini mencerminkan penilaian diri yang kuat terhadap kompetensi diri.

Selanjutnya Bonnie dan Mark (1998) menegaskan dalam penelitiannya yang menunjukkan bahwa individu yang memiliki efikasi diri tinggi pada akhirnya membawa kepada kinerja yang lebih tinggi. Sejalan dengan pandangan Bonnie dan Mark, penelitian Yeongkoo (2001) juga menunjukkan keterkaitan efikasi diri tinggi dengan kinerja, loyalitas, dan komitmen organisasi yang lebih tinggi.

Teori yang dipakai oleh peneliti untuk menjelaskan hubungan efikasi diri dengan kinerja karyawan adalah teori Brown \& Leigh (1996), yang mengatakan, efikasi diri menunjukkan bahwa individu yang memiliki kepercayaan diri bahwa ia mampu melakukan pekerjaan dengan sukses akan merasa lebih bahagia dengan pekerjaannya, sehingga mereka akan lebih fokus dalam pekerjaannya dan akan mengarahkan kepada kinerja yang lebih baik.

Berdasarkan hasil penelitian ini, maka dapat dinyatakan bahwa efikasi diri yang dimiliki oleh para pegawai PDAM Tirtanadi Cabang Sunggal dapat membantu terjadinya peningkatan kinerja karyawan. Hal ini diketahui dengan melihat bahwa efikasi diri memberikan kontribusi $72 \%$ terhadap kinerja karyawan. Hal ini mengindikasikan bahwa para pegawai PDAM Tirtanadi memiliki efikasi diri yang sangat tinggi, yang akan mengarahkan para pegawai memiliki kinerja yang sangat baik juga.

Selain efikasi diri ,banyak faktor yang dapat mempengaruhi kinerja kerja karyawan, yakni, kemampuan pegawai itu sendiri, dukungan yang diterima, keberadaan pekerjaan yang mereka lakukan serta hubungan mereka dengan organisasi. Hasil dari penelitian ini juga menetapkan bahwa efikasi diri memberikan pengaruh terhadap kinerja karyawan sebesar $72 \%$. Dari hasil ini diketahui bahwa masih terdapat $28 \%$ pengaruh dari variabel lain terhadap kinerja karyawan.

Hasil lain diperoleh dari penelitian ini, yakni diketahui bahwa subjek penelitian ini para pegawai PDAM Tirtanadi Cabang Sunggal memiliki efikasi diri yang tergolong sangat tinggi dengan kinerja karyawan yang diperoleh juga tergolong sangat tinggi. Hal ini diketahui dengan melihat nilai rata-rata/mean empiriknya efikasi diri $(175,08)$ dan nilai rata-rata hipotetiknya (105). Selanjutnya 
untuk kinerja karyawan diketahui bahwa mean rata-rata/mean empiriknya $(85,88)$ dan mean hipotetiknya adalah (8).

\section{KESIMPULAN}

Berdasarkan hasil-hasil yang telah diperoleh dalam penelitian ini, maka dapat disimpulkan hal-hal sebagai berikut:

1. Terdapat pengaruh yang signifikan antara efikasi diri terhadap kinerja karyawan. Hal ini ditunjukan dengan koefisien $\mathrm{F}_{\mathrm{reg}}=97,611$ dimana $\mathrm{p}<0,050$. menandakan bahwa semakin tinggi efikasi diri maka akan semakin baik kinerja karyawan, dan sebaliknya semakin rendah efikasi diri maka akan semakin buruk kinerja karyawan. Berdasarkan hasil penelitian ini, maka hipotesis yang diajukan dinyatakan diterima.

2. Ada pengaruh yang positif antara efikasi diri terhadap kinerja karyawan pada pegawai PDAM Tirtanadi Cabang Sunggal dengan sumbangan $72 \%$. Dari hasil ini diketahui bahwa masih terdapat $28 \%$ pengaruh dari faktor lain terhadap kinerja karyawan.

3. Hasil lain diperoleh dari penelitian ini, yakni diketahui bahwa subjek penelitian ini para pegawai PDAM Tirtanadi Cabang Sunggal, memiliki efikasi diri yang tergolong sangat tinggi dengan kinerja karyawan yang diperoleh juga tergolong sangat tinggi. Hal ini diketahui dengan melihat nilai rata-rata/mean empirik efikasi diri $(175,08)$ dan nilai rata-rata hipotetiknya (105). Selanjutnya untuk kinerja karyawan diketahui bahwa mean rata-rata/mean empiriknya $(85,88)$ dan mean hipotetiknya adalah $(8)$.

\section{DAFTAR PUSTAKA}

Abdullah, M. 2014. Manajemen dan Evaluasi Kinerja Karyawan. Yogyakarta: Aswaja Pressindo.

Bandura, Albert. 1994. Self Efficacy. Chapter in Ramachaudran, V.S. Encyclopedia of Human Behavior. New York: Academic Press.

Bandura, Albert. 1997. Self-Efficacy (The Exercise Of Control). New York: W. H. Freeman and Company.

Admin. 2015. Sejarah PDAM Tirtanadi. Diakses dari pdamtirtanadi.co.id.

Becker, T E \& Klimoski, R J. 1989. A field study of the relationship between the organizational feedback environment and performance.Journal of Personneel Psychology Vol. 42 (1989).

Bonnie. O. S. Dan Mark, M. A . 1998. Investigating Eqity Sensitivity as a Moderator of Relationship Between Self Efficacy and Workplace Attitude. Journal of Applied Psychology.

Brown, S. P., \& Leigh, T W. 1996. A New Look at Psychological Climate and Its Relationship to Job Involvement, Effort and Performance, Journal of Applied Psychology.

Cascio, W. F., \& Aguinies, H. 2005. Applied Psychology in Human Resource Management (6th Ed). New Jersey : Pearson Prentice Hall.

Hidayat, Dede Rahmat.2011. Psikologi Kepribadian dalam Konseling. Jakarta : Indeks. 
Putri, Fadiarni Widyaning. 2015. Pengaruh Efikasi Diri, Lingkungan Kerja dan Disiplin Kerja Terhadap Kinerja Pegawai Kantor Kesyahbandaran dan Otoritas Pelabuhan Kelas I Tanjung Emas Semarang. Jurnal Ekonomi dan Bisnis. Universitas Dian Nuswantoro Semarang.

Fahmi, Irham. 2013. Perilaku Organisasi: Teori,Aplikasi, dan Kasus. Bandung : Alfabeta.

Gibson, dkk. 1987. Organisasi : Perilaku, Struktur, Proses, Edisi Kelima, Jilid 1, Alih Bahasa Djarkasih,Erlangga, Jakarta.

Gomes dan Faustino, C. 2003. Manajemen Sumber Daya Manusia. Yogyakarta: Penerbit Andi.

Goleman, D. terjemahan Alex Kantjono Widodo. 1999. Kecerdasan Emosi untuk Mencapai Puncak Prestasi, Jakarta: PT. Gramedia.

Handoko, T. Hani. 2002. Manajemen Personalia dan Sumber Daya Manusia. Yogyakarta : BPFE.

Henry Simamora. 2004. Manajemen Sumber Daya Manusia. Edisi Ke-3. STIE YKPN. Yogyakarta.

Iveta, Gabcanova. "Human Resources Key Performance Indicators". Journal of Competitiveness Vol. 4 Issue 1 (Maret 2012).

Kartono, Kartini. 2002. Pemimpin dan Kepemimpinan, Jakarta: PT. Raja Grafindo Persada.

Kreitner, Robert dan Kinicki, Angelo. 2013. Perilaku Organisasi: Organizational Behavior (Buku 1) (Edisi 9), Jakarta: Salemba Empat.

Liden, C. R. dan Wayne, S. J. 2000. An examination of the Mediating Role of Psychological Empowerment on the relation Between The Job, Interpersonal Relationships, and Work Outcome.Journal of Applied Psychology. Vol. 85, No. 3.

Liza Puspita Sari. 2013 .Hubungan Antara Self Efficacy Dengan Komitmen Organisasi Guru Di SMK KH.Dewantoro Kota Tangerang Provinsi Banten .Tesis.Universitas Bina Nusantara.

Mangkunegara, Anwar Prabu AA. 2006. Evaluasi Kinerja SDM.Bandung: Refika Aditama.

Mathis.L.RobertdanJackson.H.John. 2001, Manajemen Sumber Daya Manusia,Jakarta: Buku kedua.

Mulyadi. 2007. Sistem Terpadu Pengelolaan Kinerja Personel Berbasis Balanced Scorecard. Sekolah Tinggi Ilmu Manajemen YKPN, Yogyakarta.

Mujiadi. 2003. Psikologi Perkembangan. Yogyakarta: Gadjah Mada University Press.

Moeheriono. 2012. Pengukuran Kinerja Berbasis Kompetensi. Jakarta : Raja Grafindo Persada.

Rahmani Wulandari. 2009. Pengaruh Pemberdayaan, Efikasi Diri dan Budaya Orang Terhadap Kepuasan Kerja Karyawan. Jurnal Ekonomi Manajemen. Universitas Trunojoyo Madura.

Robbins, Stephen P. 2006. Perilaku Organisasi Edisi 10. Jakarta : PT. Salemba Empat. 
Robbins, Stephen P., dan Judge, Timothy A. 2014. Perilaku Organisasi: Organizational Behavior (Buku 1) (Edisi 9), Jakarta: Salemba Empat.

Siagian, Sondang 2008. Manajemen Sumber Daya Manusia (cetakan 15). Jakarta: Bumi Aksara.

Siagian, Sondang.2002. Kepemimpinan Organisasi \& Perilaku Administrasi, Jakarta: Penerbit Gunung Agung.

Suharto dan Budhi Cahyono. 2005.Pengaruh Budaya Organisasi, Kepemimpinan dan Motivasi Kerja Terhadap Kinerja Sumber Daya Manusia di Sekretariat DPRD Propinsi Jawa Tengah.Jurnal Riset \& Bisnis Indonesia, Vol.1, No.1.

Wirawan. 2009. Evaluasi Kinerja Sumber Daya Manusia Teori Aplikasi dan Penelitian. Jakarta. Penerbit: Salemba Empat.

Yani, M. 2012. Manajemen Sumber Daya Manusia. Jakarta: Mitra Wacana Medisa.

Yeongkoo. Y. 2001. The Role of Structure and Motivation For Workplace Empowerment: The Case of Korean Employees, Social Psychology Quarterly. 